\title{
Development of resistance of mutans streptococci and Porphyromonas gingivalis to chlorhexidine digluconate and amine fluoride/stannous fluoride-containing mouthrinses, in vitro
}

\author{
Eva M. Kulik • Tuomas Waltimo • Roland Weiger • \\ Irene Schweizer • Krystyna Lenkeit • \\ Elisabeth Filipuzzi-Jenny • Clemens Walter
}

Received: 2 June 2014 / Accepted: 25 November 2014 / Published online: 9 December 2014

(C) Springer-Verlag Berlin Heidelberg 2014

\begin{abstract}
Objective The aim if this study was to determine the minimal inhibitory concentrations of chlorhexidine digluconate and an amine fluoride/stannous fluoride-containing mouthrinse against Porphyromonas gingivalis and mutans streptococci during an experimental long-term subinhibitory exposition. Material and methods Five $P$. gingivalis strains and four mutans streptococci were subcultivated for 20-30 passages in subinhibitory concentrations of chlorhexidine digluconate or an amine fluoride/stannous fluoride-containing mouthrinse. Results Pre-passaging minimal inhibitory concentrations for chlorhexidine ranged from 0.5 to $2 \mathrm{mg} / 1$ for mutans streptococci and from 2 to $4 \mathrm{mg} / \mathrm{l}$ for the $P$. gingivalis isolates. For the amine fluoride/stannous fluoride-containing mouthrinse minimal inhibitory values from 0.125 to $0.25 \%$ for the mutans streptococci and from 0.063 to $0.125 \%$ for the $P$. gingivalis isolates were determined. Two- to fourfold increased minimal inhibitory concentrations against chlorhexidine were detected for two of the five $P$. gingivalis isolates, whereas no increase in minimal inhibitory concentrations was found for the mutans streptococci after repeated passaging through subinhibitory concentrations. Repeated exposure to subinhibitory concentrations of the amine fluoride/stannous fluoride-containing mouthrinse did not alter the minimally inhibitory concentrations of the bacterial isolates tested.
\end{abstract}

E. M. Kulik • T. Waltimo $・$ I. Schweizer $\cdot$ E. Filipuzzi-Jenny Department of Preventive Dentistry and Oral Microbiology, School of Dental Medicine, University of Basel, Hebelstrasse 3, 4056, Basel, Switzerland

\section{R. Weiger $\cdot$ K. Lenkeit $\cdot$ C. Walter $(\bowtie)$}

Department of Periodontology, Endodontology and Cariology, School of Dental Medicine, University of Basel, Hebelstrasse 3, 4056 Basel, Switzerland

e-mail: clemens.walter@unibas.ch
Conclusion Chlorhexidine and the amine fluoride/stannous fluoride-containing mouthrinse are effective inhibitory agents against the oral bacterial isolates tested. No general development of resistance against chlorhexidine or the amine fluoride/ stannous fluoride-containing mouthrinse was detected. However, some strains showed potential to develop resistance against chlorhexidine after prolonged exposure.

Clinical relevance The use of chlorhexidine should be limited to short periods of time. The amine fluoride/stannous fluoridecontaining mouthrinse appears to have the potential to be used on a long-term basis.

Keywords Chlorhexidine digluconate · Amine fluoride/ stannous fluoride-containing mouthrinse $\cdot$ Porphyromonas gingivalis $\cdot$ Streptococcus mutans $\cdot$ Antimicrobial resistance

\section{Introduction}

Mouthrinses containing antimicrobial substances, including chlorhexidine or amine fluoride/stannous fluoride, are common adjuvants for oral hygiene, used to control pathogenic microorganisms or to prevent tooth decay $[33,36]$. Several indications were postulated in the last years. Mouthrinses are commonly recommended as an adjunctive measure for the treatment of periodontal diseases, including gingivitis, necrotizing, and chronic and aggressive periodontitis $[35,48]$. In addition, regular use of mouthrinses containing chlorhexidine or amine fluoride/stannous fluoride may prevent an increase of cariogenic bacteria after non-surgical periodontal therapy [9]. Mouth rinsing reduces the microbial load before oral invasive therapies [22], and last but not least, in physically disabled or medically compromised patients, mouthrinses are 
effective in reducing and preventing the incidence of severe complications, such as ventilator-associated pneumonia [51].

Chlorhexidine digluconate (CHX), a cationic biguanide was introduced as an antimicrobial agent in 1954 [7]. Because of its broad antimicrobial spectrum and high substantivity, this antiseptic is considered the "gold standard" for the control of plaque and gingivitis. However, adverse effects, including taste disturbance, tooth staining and/or irritation of the oral mucosa, and a recently suggested possible increase in blood pressure, hamper its recommendation for long-term oral use $[16,21]$.

The development of antibiotic resistance is a substantial cause for concern [24, 25, 44, 47]. Oral mouthrinses with nonselective disinfecting effect may reduce the need of systemic antibiotics, at least in severely ill medically compromised hosts. However, chlorhexidine-resistant bacterial strains, including Proteus and Klebsiella species, as well as CHXassociated changes in the bacterial cell functions have already been described [6, 13, 31, 32, 40, 41]. The emergence of resistance has not been well documented in bacteria associated with common oral diseases, including periodontitis and caries.

Periodontitis, an inflammatory disease of the periodontium that may lead to tooth loss, affects more than $60 \%$ of a population, worldwide [2, 37]. Porphyromonas gingivalis is a black-pigmented, strictly anaerobic Gram-negative rod, frequently associated with periodontitis, including aggressive and chronic forms $[45,50]$. Several strains with a supposed different pathogenic potential were described or developed for in vitro research $[45,46]$.

Caries is a highly prevalent oral disease [10, 27]. Mutans streptococci, i.e., Streptococcus mutans and Streptococcus sobrinus, are closely related to the pathogenesis of caries [19]. Prevention of caries is essential in patients with periodontitis since root surfaces are exposed, and there may be a change in the relative proportions of periodontopathogenic and cariogenic bacteria after periodontal therapy [9]. With respect to prevention of caries, mouthrinses containing amine fluoride/stannous fluoride have been shown to inhibit plaque development and support remineralization of enamel as well as to have a prolonged substantivity that enables $\mathrm{CaF}_{2}$-layer formation and thus improves the acid tolerance of the surface [33].

The aim of the present study was to analyze a potential development of bacterial resistance to chlorhexidine and to an amine fluoride/stannous fluoride-containing mouthrinse in different strains of mutans streptococci and $P$. gingivalis.

\section{Materials and methods}

Bacterial strains and growth conditions

Mutans streptococci tested were type strain S. mutans ATCC (American Type Collection) 25175, a clinical isolate S. mutans
ZIB 6121 (School of Dental Medicine, Basel, Switzerland), S. sobrinus ATCC 33402, and S. sobrinus OMZ 176 (Orale Mikrobiologie Zürich) [18]. P. gingivalis strains tested were type strain $P$. gingivalis ATCC 33277, P. gingivalis ATCC 53977, $P$. gingivalis A7436 [45], and the two clinical isolates P. gingivalis ZIB 3127 and ZIB 3016 (School of Dental Medicine, Basel, Switzerland).

The bacteria were maintained on Columbia blood agar plates (Columbia Agar Base (BBL Becton Dickinson, Allschwil, Switzerland) supplemented with $5 \mathrm{mg} / 1$ hemin, $0.5 \mathrm{mg} / 1 \mathrm{menadione}$, and $50 \mathrm{ml} / 1$ human blood) at $36{ }^{\circ} \mathrm{C}$. Streptococci were incubated in $10 \% \mathrm{CO}_{2}+$ air for $2-3$ days and $P$. gingivalis strains anaerobically $\left(10 \% \mathrm{CO}_{2}, 10 \% \mathrm{H}_{2}\right.$, $80 \% \mathrm{~N}_{2}$ ) for 7 days.

\section{Test substances}

The $20 \%$ chlorhexidine digluconate (CHX) solution was purchased from Sigma-Aldrich Chemie GmbH (Buchs, Switzerland), and a $0.2 \%$ stock solution was prepared in $\mathrm{H}_{2} \mathrm{O}$. An amine fluoride/stannous fluoride $\left(\mathrm{AmF} / \mathrm{SnF}_{2} \quad 0.025 \% \mathrm{~F}^{-}\right)$ containing mouthrinse (Meridol ${ }^{\circledR}$ mouthrinse, Gaba, Therwil, Switzerland) was used for comparison.

The stock solutions were further serially diluted in Columbia Broth (BBL Becton Dickinson, Allschwil, Switzerland) supplemented with $5 \mathrm{mg} / \mathrm{l}$ hemin and $0.5 \mathrm{mg} / \mathrm{l}$ menadione for P. gingivalis or in Columbia Broth (BBL Becton Dickinson, Allschwil, Switzerland) for mutans streptococci.

Passaging of bacteria in subinhibitory concentration of test substances

Minimum inhibitory concentration (MIC) values were determined by a macrodilution broth method according to the CLSI guidelines [5]. Bacterial cells were removed from the agar plates with sterile cotton swabs and suspended in the respective broth media to a concentration of McFarland 2. These microbial suspensions were adjusted to a final cell density of approximately $1 \times 10^{7} \mathrm{CFU} / \mathrm{ml}$ and controlled by plating $100 \mu \mathrm{l}$ of appropriate dilutions ranging from $10^{-3}$ to $10^{-6}$ onto Columbia blood agar plates. An aliquot of $100 \mu \mathrm{l}$ of the bacterial suspensions was then added to $2 \mathrm{ml}$ each of the serial dilutions described above.

After incubation at $37{ }^{\circ} \mathrm{C}$ for either 2-3 days (mutans streptococci) or 7 days (P. gingivalis), the MIC values were recorded. The MIC value was defined as the lowest concentration of the test substances at which the microorganism did not show any visible growth. The culture tube below the MIC, which corresponds to the highest subinhibitory concentration, was then used to prepare the inoculum for the next transfer, and an aliquot was stored in $20 \%$ glycerol at $-70{ }^{\circ} \mathrm{C}$. This selection through subinhibitory concentrations of $\mathrm{CHX}$ or the amine fluoride/stannous fluoride-containing mouthrinse was 
done for 20 or 30 passages, and the MIC value was recorded after each passage.

As controls, the serial dilutions of the test substances in medium were incubated as well (negative control). Additionally, $100 \mu \mathrm{l}$ of the bacterial suspensions used as inoculations were plated on Columbia blood agar plates supplemented with $5 \mathrm{mg} / 1$ hemin, $0.5 \mathrm{mg} / 1$ menadione, and $50 \mathrm{ml} / 1$ human blood and incubated accordingly (positive control).

Two independent experiments were performed throughout the study.

\section{Results}

Pre-passage MIC values

The MIC values obtained during passaging of the four mutans streptococci in subinhibitory concentrations of either the $\mathrm{AmF} / \mathrm{SnF}_{2}$-containing mouthrinse or $\mathrm{CHX}$ are shown in Figs. 1 and 2, whereas those for the five $P$. gingivalis isolates are presented in Figs. 3 and 4, respectively.

Pre-passage $\mathrm{MIC}$ values for the $\mathrm{AmF} / \mathrm{SnF}_{2}$-containing mouthrinse (Figs. 1 and 3) were comparable for both bacterial species varying between 0.063 and $0.25 \%$ (corresponding to

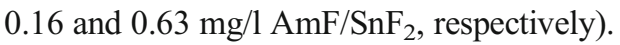

For $\mathrm{CHX}$, the pre-passage MIC values were from 0.5 to $2 \mathrm{mg} / \mathrm{l}$ for mutans streptococci (Fig. 2) and from 2 to $4 \mathrm{mg} / 1$ for the $P$. gingivalis isolates (Fig. 4).

Exposure to subinhibitory concentrations of the amine fluoride/stannous fluoride-containing mouthrinse

Repeated exposure to subinhibitory concentrations of the $\mathrm{AmF} / \mathrm{SnF}_{2}$-containing mouthrinse did not alter the MIC values of the bacterial isolates tested (Figs. 1 and 3). Whereas the MIC values for the $P$. gingivalis isolates were stable within \pm one serial dilution (Fig. 3), larger variations were noticed for the mutans streptococci (Fig. 1). With the exception of $S$. mutans ATCC 25175, no trend towards higher MIC values was observed during the 20 passages in subinhibitory concentration of the $\mathrm{AmF} / \mathrm{SnF}_{2}$-containing mouthrinse.

To check for genetic stability during passaging, the bacterial suspensions were analyzed by random amplified polymorphic DNA (RAPD) fingerprinting using two different primers for each bacterial species. For both primers, the RAPD profiles were stable over the course of the experiments (data not shown).

Exposure to subinhibitory concentrations of $\mathrm{CHX}$

The variability between both experiments was low for the P. gingivalis isolates (Fig. 4). However, the MIC values during the 20 passages in subinhibitory concentrations of $\mathrm{CHX}$ showed larger variations for the mutans streptococci (Fig. 2).

For some of the bacterial strains, increases of CHX MIC values of two- or fourfold were observed during the 20 passages in CHX. Therefore, two $P$. gingivalis isolates, namely A7436 and ZIB 3016, were investigated for additional ten passages in subinhibitory concentrations of CHX. For $P$. gingivalis A7436, the MIC values increased from a prepassage MIC value of 4 to $8 \mathrm{mg} / \mathrm{l}$ at passage 13 and to $16 \mathrm{mg} / \mathrm{l}$ at passage 29 . The strain ZIB 3016 showed varying susceptibility. After a pre-passage MIC value of $2 \mathrm{mg} / \mathrm{l}$, this value increased to $4 \mathrm{mg} / \mathrm{l}$ at passage 7 and to $8 \mathrm{mg} / \mathrm{l}$ at passage 16 . Afterwards, the MIC values fluctuated between 4 and $8 \mathrm{mg} / 1$ (data not shown). As before, the bacterial suspensions were analyzed by RAPD fingerprinting using two different primers for each bacterial species. The RAPD profiles were stable over the course of the experiments (data not shown).

\section{Discussion}

The results of this in vitro study using a macrodilution assay with up to 30 passages in liquid broth showed a two- to fourfold increase in MIC values to $\mathrm{CHX}$ in the two P. gingivalis strains A7436 and ZIB 3016. However, no such increase was observed for mutans streptococci challenged with subinhibitory concentrations of $\mathrm{CHX}$ or the $\mathrm{AmF} / \mathrm{SnF}_{2}-$ containing mouthrinse.

Mouthrinses containing antimicrobial substances are commonly used on a daily basis to control and prevent dental diseases by providing a complementary mechanism of plaque control. Various products are commercially available containing different active ingredients. Among them, chlorhexidine digluconate is still considered to be the "gold standard." However, it is not recommended for long-term use due to its numerous adverse effects [16]. Alternative mouthrinses containing antimicrobial agents, including the antimicrobial agents octenidine, polyhexamethylene biguanide, cetylpyridinium chloride, essential oils, or fluorides, have already entered the market [33, 36]. The amine fluoride/ stannous fluoride combination is a potent compound to control oral microorganisms and has been found to be in vitro as efficient as CHX against some oral microorganisms [15, 26].

In our study, we used a broth macrodilution assay [42] to determine the MIC values of the oral bacterial isolates during 20 or 30 passages through subinhibitory concentrations of either $\mathrm{CHX}$ - or the $\mathrm{AmF} / \mathrm{SnF}_{2}$-containing mouthrinse. Prepassage MIC values of both compounds against mutans streptococci and $P$. gingivalis isolates were well below the respective concentrations used in commercially available mouthrinses. The MIC values of CHX were in agreement with other studies for both bacterial species with the Gram-positive 
Mutans Streptococci I amine fluoride/stannous fluoride containing mouthrinse

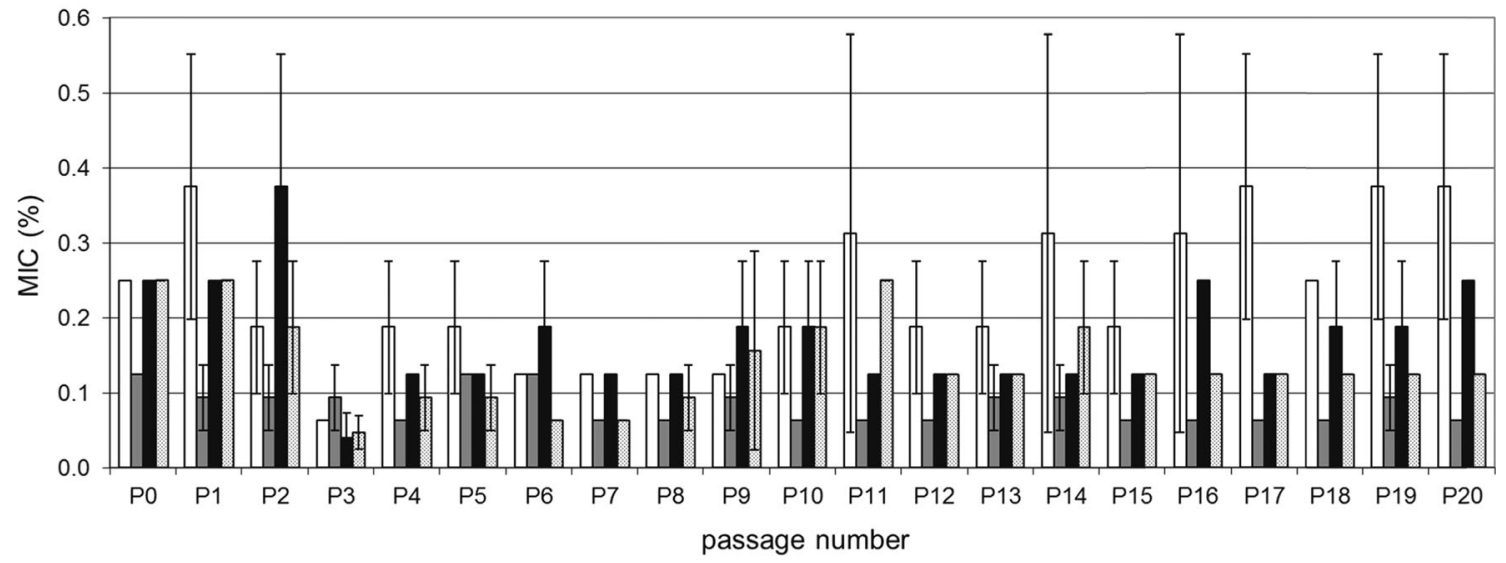

Fig. 1 Susceptibility of mutans streptococci to the amine fluoride/ stannous fluoride-containing mouthrinse. Shown are the mean MIC values (in \% mouthrinse) and the respective standard deviation of S. mutans ATCC 25175 (white), S. mutans ZIB 6121 (grey), S. sobrinus

mutans streptococci being more susceptible to CHX than the Gram-negative $P$. gingivalis isolates [20, 23, 26, 39]. Also, the pre-passage $\mathrm{MIC}$ values for the $\mathrm{AmF} / \mathrm{SnF}_{2}$-containing mouthrinse were in the same range for both oral bacterial species. With values between 0.063 and $0.25 \%$ of the commercially available mouthrinse (corresponding to 0.16 to $0.63 \mathrm{mg} / \mathrm{l} \mathrm{AmF} / \mathrm{SnF}_{2}$ ), they were slightly lower compared to other studies $[15,26]$.

During the 20 passages in subinhibitory concentrations of $\mathrm{CHX}$ - or the $\mathrm{AmF} / \mathrm{SnF}_{2}$-containing mouthrinse, the $\mathrm{MIC}$ values fluctuated mostly within \pm one serial dilution of the pre-passage MIC values and only transitory increases occurred. Larger variations were noticed for the mutans streptococci as compared to the $P$. gingivalis isolates. However, higher CHX MIC values were observed for two out of five $P$. gingivalis isolates.
ATCC 33402 (black), and S. sobrinus OMZ 176 (dotted) during 20 passages in subinhibitory concentrations of the amine fluoride/stannous fluoride-containing mouthrinse. $P 0$ pre-passage

Our results are to some extent in concordance with results from a study using an agar-dilution technique for various oral microorganisms including $P$. gingivalis [12]. Although differences between both studies exists, i.e., much higher prepassaging MIC values than in our study and other bacterial strains used, only a transitory moderate increase in the tolerance to CHX was observed [12]. A twofold increase in MIC for three out of eight $P$. gingivalis isolates and for one out of ten streptococcal strains was demonstrated after 25 passages on agar plates containing subinhibitory concentrations of CHX. For the $\mathrm{AmF} / \mathrm{SnF}_{2}$-containing mouthrinse, a twofold increase was noticed for four out of ten $P$. gingivalis isolates [12].

In contrast to the situation with antibiotics, no clear definition of biocide resistance exists so far. Only recently, the epidemiological cutoff values (ECOFFs) against some common biocides including CHX has been determined in 3327

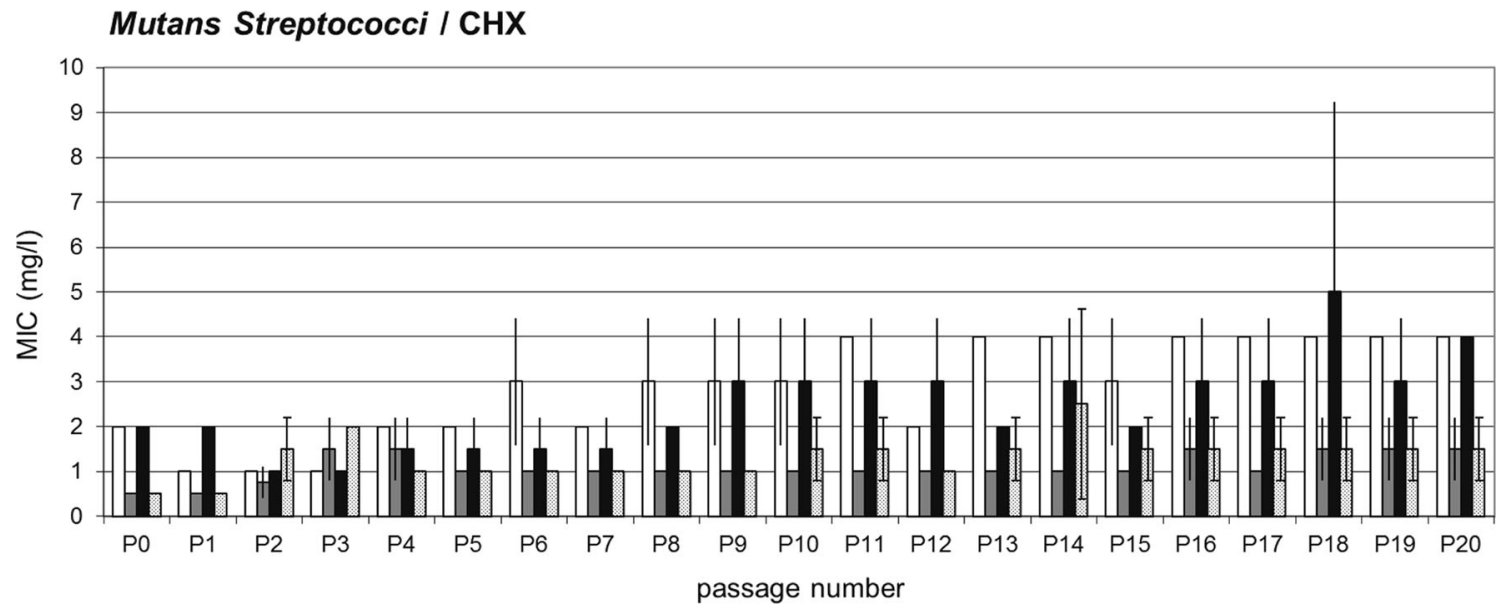

Fig. 2 Susceptibility of mutans streptococci to CHX. Shown are the mean MIC values (in $\mathrm{mg} / \mathrm{l} \mathrm{CHX)}$ ) and the respective standard deviation of S. mutans ATCC 25175 (white), S. mutans ZIB 6121 (grey), S. sobrinus
ATCC 33402 (black), and S. sobrinus OMZ 176 (dotted) during 20 passages in subinhibitory concentrations of $\mathrm{CHX}$. $\mathrm{PO}$ pre-passage 


\section{P. gingivalis / amine fluoride/stannous fluoride containing mouthrinse}

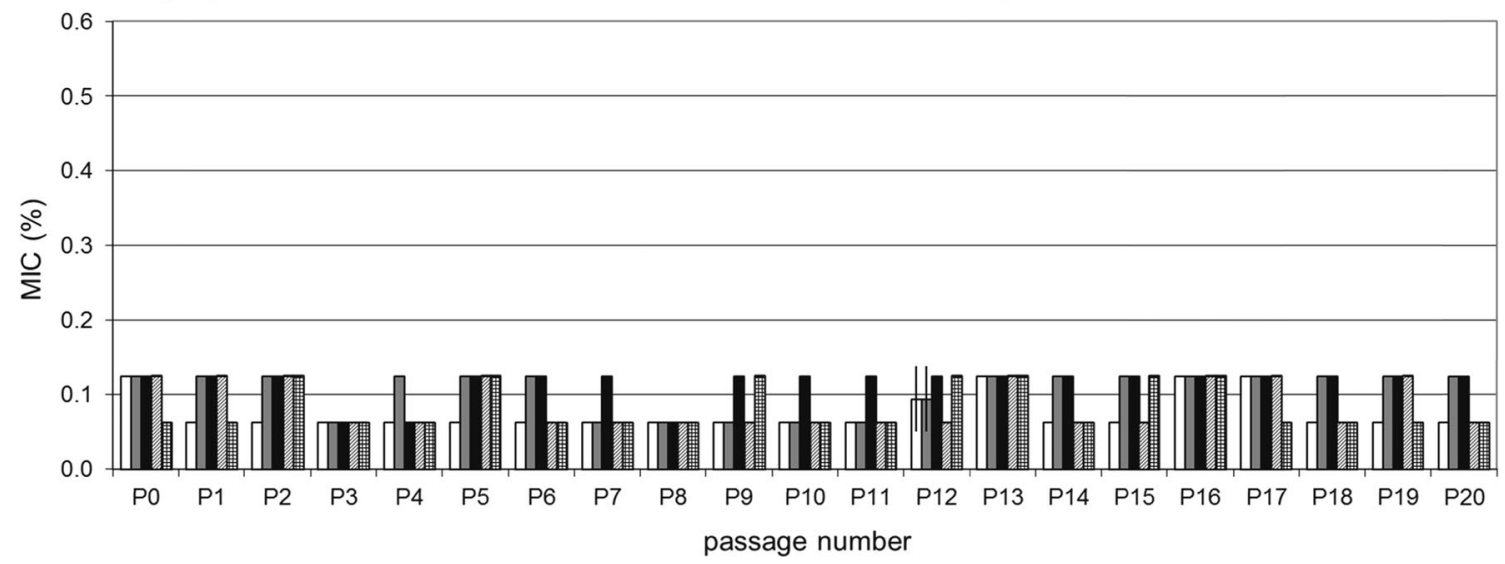

Fig. 3 Susceptibility of $P$. gingivalis to the amine fluoride/stannous fluoride-containing mouthrinse. Shown are the mean MIC values (in \% mouthrinse) and the respective standard deviation of $P$. gingivalis isolates

natural isolates of clinically relevant microorganisms [29]. In most cases, the MIC ECOFF values followed a normal distribution indicating the absence of biocide-resistant subpopulations. The MIC ECOFF values of CHX were shown to be between 8 and $64 \mathrm{mg} / 1$ for Gram-positive and between 16 and $64 \mathrm{mg} / \mathrm{l}$ for Gram-negative bacteria [29]. As oral isolates were not included in this analysis, it is not possible to extrapolate these MIC ECOFF values of CHX to the MIC values obtained in our study.

More than 700 bacterial species or phylotypes inhabit the oral cavity commonly organized as complex biofilms [1]. Therefore, to fully evaluate the potential of resistance development, commensals but also other pathogenic oral species need to be tested as well. Although biofilm models exist, the enormous variety of the oral microflora makes it very challenging to mimic the intraoral situation in a laboratory biofilm model.

With $P$. gingivalis and mutans streptococci, prominent members of the oral bacterial community were selected in this
ATCC 53977 (white), ATCC 33277 (grey), A7436 (black), ZIB 3127 (hatched), and ZIB 3016 (cross-hatched) during 20 passages in subinhibitory concentrations of CHX. $P 0$ pre-passage

study. The association of $P$. gingivalis with different periodontal diseases was shown by Socransky et al. [38], Moore and Moore [28], and others. Different $P$. gingivalis strains showed differing pathogenic activity or a differing expression of potential virulence factors, both in animal models and in vitro examinations [3, 11, 45]. Also in our study, five different $P$. gingivalis isolates with suspected different virulence capacities were analyzed [45]. Sensitivity against CHX seems to differ among the strains analyzed in this study.

No differences were found in the RAPD profiles over the course of the experiments for both bacterial species after exposure to both mouthrinses, indicating genetic stability during passaging $[8,49]$. A more in-depth analysis of potential DNA mutations that might have arisen during prolonged exposure to the mouthrinses could involve the use of more RAPD primers and/or the use of other molecular approaches such as denaturing gradient gel electrophoresis or pulsed-field gel electrophoresis.

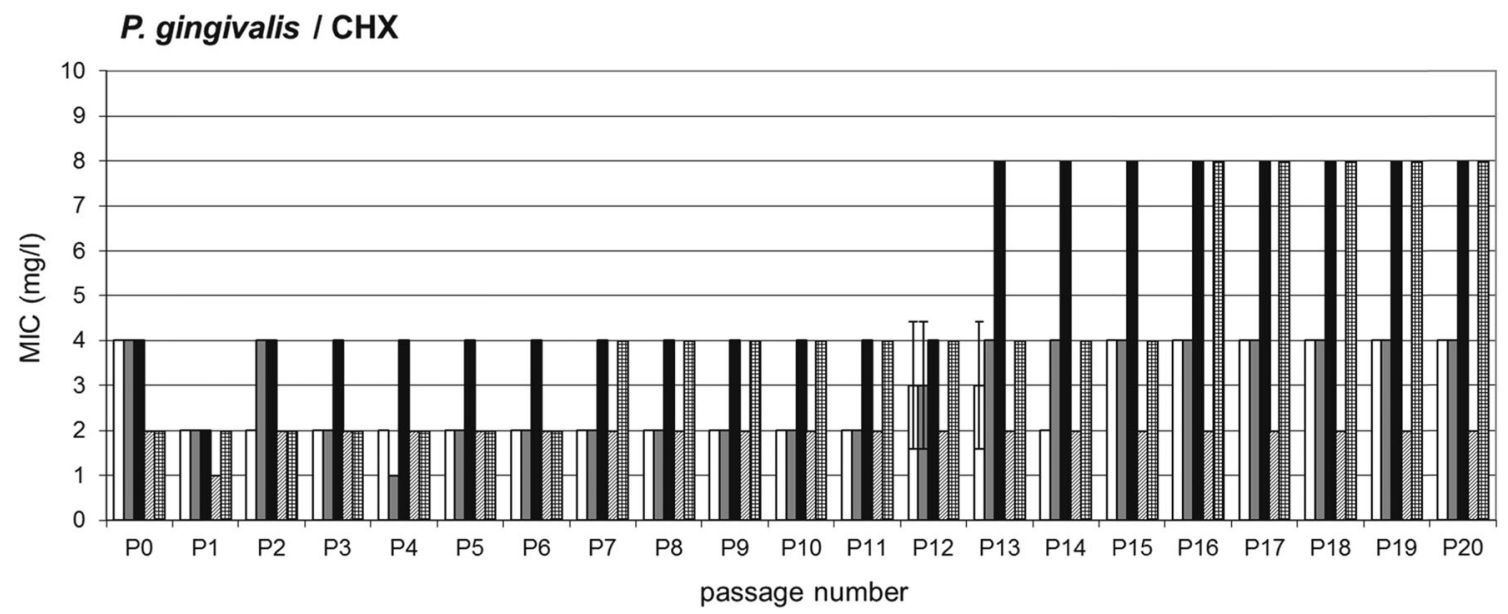

Fig. 4 Susceptibility of $P$. gingivalis to CHX. Shown are the mean MIC values (in $\mathrm{mg} / \mathrm{l} \mathrm{CHX}$ ) and the respective standard deviation of P. gingivalis isolates ATCC 53977 (white), ATCC 33277 (grey), A7436 (black), ZIB 3127 (hatched), and ZIB 3016 (cross-hatched) during 20 passages in subinhibitory concentrations of $\mathrm{CHX}$. $P 0$ pre-passage 
Our results indicate that the $\mathrm{AmF} / \mathrm{SnF}_{2}$-containing mouthrinse may not lead to an increase in resistance and might therefore have the potential to be used on a long-term basis. However, such a long-term use of CHX-containing mouthrinses may cause the development of microbial resistance $[6,13,31,32,34,40,41]$, although the associated mechanisms are not well understood $[14,30]$. Changes in the cell wall functions of Gram-negative bacteria, such as multidrug efflux pumps possibly encoded by plasmids, have been proposed [14]. In contrast, there is no evidence to support the hypothesis that Gram-positive oral streptococci will develop resistance against CHX during a short-term clinical use [20].

There are several mechanisms by which biocide-resistant microorganisms can arise. Microorganisms can be intrinsically resistant to biocide through the presence of a permeability barrier or efflux systems, through physiological resistance when organized in a biofilm or by inactivation of the biocide. Acquired resistance can be gained by target alterations, i.e., mutations in genes that are responsible for the formation of cell wall, membrane lipids, porins or OMPs, or by the acquisition of biocide resistance genes through horizontal transfer [4, 17, 43].

Repeated exposure to subinhibitory concentrations of the $\mathrm{AmF} / \mathrm{SnF}_{2}$-containing mouthrinse did not alter the MIC values of the bacterial isolates tested, whereas chlorhexidine could cause a two- to fourfold increase in MIC values in $P$. gingivalis strains after passaging in liquid broth. Differences between strains are evident. However, since mouthrinses containing chlorhexidine are widely used, the development of chlorhexidine-resistant microbial strains may possibly occur; therefore, in addition to a rational use for distinct reasonable indications, further investigations on alternatives to chlorhexidine are prevailingly rational.

Conflict of interest The authors declare that they have no conflicts of interest.

\section{References}

1. Aas JA, Paster BJ, Stokes LN, Olsen I, Dewhirst FE (2005) Defining the normal bacterial flora of the oral cavity. J Clin Microbiol 43: 5721-5732

2. Albandar JM, Tinoco EM (2002) Global epidemiology of periodontal diseases in children and young persons. Periodontol 2000 29:153176

3. Bostanci N, Belibasakis GN (2012) Porphyromonas gingivalis: an invasive and evasive opportunistic oral pathogen. FEMS Microbiol Lett 333:1-9

4. Bridier A, Briandet R, Thomas V, Dubois-Brissonnet F (2011) Resistance of bacterial biofilms to disinfectants: a review. Biofouling 27:1017-1032

5. Clinical and Laboratory Standards Institute (2007) Methods for antimicrobial susceptibility testing of anaerobic bacteria; approved standard M11-A7. CLSI, Wayne, USA
6. Davies A, Roberts W (1969) The cell wall of a chlorhexidineresistant Pseudomonas. Biochem J 112:15P

7. Davies GE, Francis J, Martin AR, Rose FL, Swain G (1954) 1:6-Di4'-chlorophenyldiguanidohexane (hibitane); laboratory investigation of a new antibacterial agent of high potency. Br J Pharmacol Chemother 9:192-196

8. de Lastours V, Cambau E, Guillard T, Marcade G, Chau F, Fantin B (2012) Diversity of individual dynamic patterns of emergence of resistance to quinolones in Escherichia coli from the fecal flora of healthy volunteers exposed to ciprofloxacin. J Infect Dis 206:1399 1406

9. De Soete M, Dekeyser C, Pauwels M, Teughels W, van Steenberghe D, Quirynen M (2005) Increase in cariogenic bacteria after initial periodontal therapy. J Dent Res 84:48-53

10. Do LG (2012) Distribution of caries in children: variations between and within populations. J Dent Res 91:536-543

11. Eick S, Rodel J, Einax JW, Pfister W (2002) Interaction of Porphyromonas gingivalis with $\mathrm{KB}$ cells: comparison of different clinical isolates. Oral Microbiol Immunol 17:201-208

12. Eick S, Goltz S, Nietzsche S, Jentsch H, Pfister W (2011) Efficacy of chlorhexidine digluconate-containing formulations and other mouthrinses against periodontopathogenic microorganisms. Quintessence Int 42:687-700

13. el Moug T, Rogers DT, Furr JR, el-Falaha BM, Russell AD (1985) Antiseptic-induced changes in the cell surface of a chlorhexidinesensitive and a chlorhexidine-resistant strain of Providencia stuartii. $\mathrm{J}$ Antimicrob Chemother 16:685-689

14. Fang CT, Chen HC, Chuang YP, Chang SC, Wang JT (2002) Cloning of a cation efflux pump gene associated with chlorhexidine resistance in Klebsiella pneumoniae. Antimicrob Agents Chemother 46:2024-2028

15. Flisfisch S, Meyer J, Meurman JH, Waltimo T (2008) Effects of fluorides on Candida albicans. Oral Dis 14:296-301

16. Flötra L, Gjermo P, Rolla G, Waerhaug J (1971) Side effects of chlorhexidine mouth washes. Scand J Dent Res 79:119-125

17. Gnanadhas DP, Marathe SA, Chakravortty D (2013) Biocides-resistance, cross-resistance mechanisms and assessment. Expert Opin Investig Drugs 22:191-206

18. Guggenheim B, Schroeder HE (1967) Biochemical and morphological aspects of extracellular polysaccharides produced by cariogenic streptococci. Helv Odontol Acta 11:131-152

19. Hamada S, Slade HD (1980) Biology, immunology, and cariogenicity of Streptococcus mutans. Microbiol Rev 44:331-384

20. Jarvinen H, Tenovuo J, Huovinen P (1993) In vitro susceptibility of Streptococcus mutans to chlorhexidine and six other antimicrobial agents. Antimicrob Agents Chemother 37:1158-1159

21. Kapil V, Haydar SM, Pearl V, Lundberg JO, Weitzberg E, Ahluwalia A (2013) Physiological role for nitrate-reducing oral bacteria in blood pressure control. Free Radic Biol Med 55:93-100

22. Kosutic D, Uglesic V, Perkovic D, Persic Z, Solman L, Lupi-Ferandin S, Knezevic P, Sokler K, Knezevic G (2009) Preoperative antiseptics in clean/contaminated maxillofacial and oral surgery: prospective randomized study. Int J Oral Maxillofac Surg 38:160-165

23. Kulik E, Lenkeit K, Meyer J (2000) Antimicrobial effects of tea tree oil (Melaleuca alternifolia) on oral microorganisms. Schweiz Monatsschr Zahnmed 110:125-130

24. Kulik EM, Lenkeit K, Chenaux S, Meyer J (2008) Antimicrobial susceptibility of periodontopathogenic bacteria. J Antimicrob Chemother 61:1087-1091

25. Kulik Kunz EM, Lenkeit K, Waltimo T, Weiger R, Walter C (2004) Combinatorial effects of amoxicillin and metronidazole on selected periodontal bacteria and whole plaque samples. Arch Oral Biol 59: 608-615

26. Meurman JH, Jousimies-Somer H, Suomala P, Alaluusua S, Torkko $\mathrm{H}$, Asikainen S (1989) Activity of amine-stannous fluoride combination and chlorhexidine against some aerobic and anaerobic oral bacteria. Oral Microbiol Immunol 4:117-119 
27. Micheelis W (2011) Oral health in Germany: an oral epidemiological outline. Bundesgesundheitsblatt Gesundheitsforschung Gesundheitsschutz 54:1022-1026

28. Moore WE, Moore LV (1994) The bacteria of periodontal diseases. Periodontol 2000 5:66-77

29. Morrissey I, Oggioni MR, Knight D, Curiao T, Coque T, Kalkanci A, Martinez JL (2014) Evaluation of epidemiological cut-off values indicates that biocide resistant subpopulations are uncommon in natural isolates of clinically-relevant microorganisms. PLoS One 9: e86669

30. Nagai I, Ogase H (1990) Absence of role for plasmids in resistance to multiple disinfectants in three strains of bacteria. J Hosp Infect 15: 149-155

31. Nakahara H, Kozukue H (1981) Chlorhexidine resistance in Escherichia coli isolated from clinical lesions. Zentralbl Bakteriol Mikrobiol Hyg A 251:177-184

32. Nakahara H, Kozukue H (1982) Isolation of chlorhexidine-resistant Pseudomonas aeruginosa from clinical lesions. J Clin Microbiol 15: 166-168

33. Netuschil L, Weiger R, Preisler R, Brecx M (1995) Plaque bacteria counts and vitality during chlorhexidine, Meridol and Listerine mouthrinses. Eur J Oral Sci 103:355-361

34. Nicoletti G, Boghossian V, Gurevitch F, Borland R, Morgenroth P (1993) The antimicrobial activity in vitro of chlorhexidine, a mixture of isothiazolinones ('Kathon' CG) and cetyl trimethyl ammonium bromide (CTAB). J Hosp Infect 23:87-111

35. Quirynen M, Mongardini C, Pauwels M, Bollen CM, Van Eldere J, van Steenberghe D (1999) One stage full- versus partial-mouth disinfection in the treatment of chronic adult or generalized earlyonset periodontitis. II. Long-term impact on microbial load. J Periodontol 70:646-656

36. Rohrer N, Widmer AF, Waltimo T, Kulik EM, Weiger R, FilipuzziJenny E, Walter C (2010) Antimicrobial efficacy of 3 oral antiseptics containing octenidine, polyhexamethylene biguanide, or Citroxx: can chlorhexidine be replaced? Infect Control Hosp Epidemiol 31:733739

37. Schürch E Jr, Lang NP (2004) Periodontal conditions in Switzerland at the end of the 20th century. Oral Health Prev Dent 2:359-368

38. Socransky SS, Haffajee AD, Cugini MA, Smith C, Kent RL Jr (1998) Microbial complexes in subgingival plaque. J Clin Periodontol 25: 134-144
39. Solmaz G, Korachi M (2012) Inhibition and disruption properties of chlorhexidine gluconate on single and multispecies oral biofilms. Jundishapur J Microbiol 6:61-66

40. Stickler DJ (1974) Chlorhexidine resistance in Proteus mirabilis. J Clin Pathol 27:284-287

41. Stickler DJ (2002) Susceptibility of antibiotic-resistant Gram-negative bacteria to biocides: a perspective from the study of catheter biofilms. J Appl Microbiol 92:163S-170S

42. Tambe SM, Sampath L, Modak SM (2001) In vitro evaluation of the risk of developing bacterial resistance to antiseptics and antibiotics used in medical devices. J Antimicrob Chemother 47:589-598

43. Tumah HN (2009) Bacterial biocide resistance. J Chemother 21:5-15

44. van Winkelhoff AJ, Herrera D, Oteo A, Sanz M (2005) Antimicrobial profiles of periodontal pathogens isolated from periodontitis patients in The Netherlands and Spain. J Clin Periodontol 32:893-898

45. Walter C, Zahlten J, Schmeck B, Schaudinn C, Hippenstiel S, Frisch E, Hocke AC, Pischon N, Kuramitsu HK, Bernimoulin JP, Suttorp N, Krull M (2004) Porphyromonas gingivalis strain-dependent activation of human endothelial cells. Infect Immun 72:5910-5918

46. Walter C, Purucker P, Bernimoulin JP, Suttorp N, Meyer J, Weiger R (2005) Critical assessment of microbiological diagnostics in periodontal diseases with special focus on Porphyromonas gingivalis. Schweiz Monatsschr Zahnmed 115:415-424

47. Walter C, Weiger R (2006) Antibiotics as the only therapy of untreated chronic periodontitis: a critical commentary. J Clin Periodontol 33: 938-939

48. Walter C, Buset S, Thillainathan L, Weiger R, Zitzmann NU (2013) Evaluation of periodontal therapy in undergraduate courses of the University of Basle. A retrospective study. Schweiz Monatsschr Zahnmed 123:861-877

49. Westbrook SD, Wiederhold NP, Vallor AC, Kotara S, Bernardo S, Lee SA, Kirkpatrick WR, Toro JJ, Freytes C, Patterson TF, Redding SW (2010) Loss of in vitro resistance in Candida glabrata following discontinuation of fluconazole prophylaxis in a hematopoietic stem cell transplantation patient. Med Mycol 48:557-560

50. Zahlten J, Riep B, Nichols FC, Walter C, Schmeck B, Bernimoulin JP, Hippenstiel S (2007) Porphyromonas gingivalis dihydroceramides induce apoptosis in endothelial cells. J Dent Res 86:635-640

51. Zhang TT, Tang SS, Fu LJ (2013) The effectiveness of different concentrations of chlorhexidine for prevention of ventilatorassociated pneumonia: a meta-analysis. J Clin Nurs 23:1461-1475 